\title{
New tendencies in public administration: from the new public management (NPM) and new governance (NG) to e-government
}

\author{
Dorina Țicu ${ }^{1}$ \\ 1 "Alexandru Ioan Cuza" University, Faculty of Philosophy and Social and Political Studies, Department \\ of Political Sciences, International Relations and European Studies20 Boulevard Carol I, Iasi, Romania
}

\begin{abstract}
This article aims to realize an analysis on the current public administration through the prism of new explanatory theories: The New Governance (NG) and the New Public Management (NPM), beyond the classical bureaucratic theories, the sociological theories, etc. The article is based on a qualitative analysis of the local public administrative system: trying to identify whether the elements of e-government are present at this level, as well as what their role and their necessity are at the publicadministrative level by correspondence with the new theories applied, presented above: NG and NPM.
\end{abstract}

\section{Introduction. The Public Administration - starting from the classical theories}

The Public Administration is a well-known concept, quite old, subjected to numerous analyses, starting from the bureaucratic theories. Starting from the Weberian vision, the bureaucracy as a theory that explains the decision-making process in the public space differentiates between the politicians and the bureaucrats and establishes the conditions under which the public administration representatives can make decisions, such as: clear identification of the duties through the perspective of the job description, the establishment and clear observance of the hierarchies, the procedural institutionalization of the decisionmaking process on the basis of depersonalized rules and laws, the work for the good of the community and the management of the public goods and services in the light of the mentioned principle, etc. Public Administration (PA) is directly linked to the idea of the governance and of the government, "having the role of solving social problems" (Lee, 2003: $5)$.

The key elements of the traditional PA can be defined as: "the dominance of the "rule of law"; a focus on administering set rules and guidelines; a central role for the bureaucracy in policy making and implementation; the politics - administration split within public organizations; a commitment to incremental budgeting; and the hegemony of the professional in the service delivery system" (Osborne, 2006: 378).

From this point of view, the Traditional Public Administration would acquire more or, above all, less favourable images over time because of the fact that the provision of public goods and services, of social services, at the level of a community, without fail, both in terms 
of accessibility and effectiveness and efficiency, remains a variable that we consider to require adaptations and readjustments, depending on both local and regional, national or international developments of States and bodies dictating or influencing finances, resources, international markets, etc.

\section{New Perspectives at Administrative Level: New Public Management (NPM)}

The term New Public Management (NMP) was first used by Christopher Hood in 1990, when he observed forms of administration at OECD level in the 1980s (Adroniceanu, Şandor, 2006: 13).

The New Public Management has the following characteristics: the introduction of the principle of budgeting based on null-sum games (we can say a lack of security on budgeting), the objective-based management, the measurement of the performance through different techniques and technologies, the measurement of the organization's leader's form, the imposition of the rational management (based on rational actor theory as a principle of judgment - including principles of efficiency and effectiveness), but also the individualism as a competition beat, as well as a clear formula for ranking of any roles identified at administrative level (Maesschalck, 2004: 471). Gruening, summarizes these differences and completes them in Table 1:

Table 1. Features of New Public Management (NPM) (Gruening, 2001:2)

\begin{tabular}{ll} 
Characteristics of the New Public Management \\
$\begin{array}{ll}\text { Undisputed characteristics (identified by most } \\
\text { observers) }\end{array}$ & $\begin{array}{l}\text { Debatable attributes (identified by some, but not all, } \\
\text { observers) }\end{array}$ \\
\hline $\begin{array}{l}\text { Budget cuts } \\
\text { Vouchers }\end{array}$ & $\begin{array}{l}\text { Legal, budget, and spending constraints } \\
\text { Rationalization of jurisdictions } \\
\text { Accountability for performance }\end{array}$ \\
$\begin{array}{l}\text { Pelicy analysis and evaluation } \\
\text { Improved regulation }\end{array}$ \\
Privatization & $\begin{array}{c}\text { Rationalization or streamlining of administrative } \\
\text { structures } \\
\text { Democratization and citizen participation }\end{array}$ \\
Customers (one-stop shops, case management) & \\
Decentralization & \\
Strategic planning and management & \\
Separation of provision and production & \\
Competition & \\
Performance measurement & \\
Changed management style & \\
Contracting out & \\
Freedom to manage (flexibility) & \\
Improved accounting & \\
Personnel management (incentives) & \\
User charges & \\
Separation of politics and administration & \\
Improved financial management & More use of information technology
\end{tabular}

Referring to the New Public Management, Androniceanu analyses the concept from the perspective of performance at the level of the administrative system. Thus, the New Public Management assumes the following characteristics: the clear definition of the term of performance at administrative level and the concrete identification of applicable performance criteria and indices; the customized approach of each specific area of public administration and the establishment of specific performance indices and indicators; the adapting methods of analysis to the diversity of types of public services offered at administrative level - from central to local level; the unitary coordination of the applied performance criteria, which nevertheless retain their specificities according to the typology of services and public goods; etc 
The process of measuring performance in the public sector is, as the scholars admit, a particularly difficult one for several reasons:

- the multitude and the diversity of the stakeholders of a public institution: the current and the potential customers, the voting citizens, the elected representatives, the non-profit organisations, the professional groups, the trade unions, the public managers, the state, the political parties, etc.;

- the differences in values and perceptions of performance that the different stakeholders have;

- the absence of a competitive environment in which some services are offered, due to the monopoly position of some public institutions or administrative authorities;

- the nature, complexity and diversity of the public service provided;

- the complexity of the socio-political environment that generates a number of risks with direct implication on achieving performance;

- the influence of political values, the bargaining power of performance level and the coordinates of the democracy which are key factors of success in achieving performance in the public sector (Androniceanu, 2003: 18).

Doorgapesad identifies the following features when he analyses the New Public Management: the decentralization of the administrative institutional system - by creating specialized agencies and departments at sub-national levels; the external contracting - by outsourcing certain activities, including the provision of certain goods and services; the performance contracting - through negotiations between the State and agencies fighting in a competitive market for public services; the corporatization - by employing certain civil servants in agency structures to have mixed staff structure and exchange of experience (Doorgapersad, $2011: 239-240$ ).

The role of the New Public Management in the development of Public Administration should be noted. The paradigm brings with it the market criteria and performance in the generation and the provision of public goods and services, which often leads to an increase in their quality and can also lead to the formation of the prices according to the principle of supply and demand, proposing to ensure lower levels of them. The creation of some decentralized and hybrid administrative structures requires and can ensure the performance and professionalization of the civil servants in the system, which brings this kind of paradigm closer to the principles by which the market operates.

However, the New Public Mnaniment has failed to solve the problem of governance or the generation of the best solution for securing public goods and services. Thus seen, the New Public Managment did not produce a decrease in bureaucracy, but an increase in administrative structures and implicitly of their costs, and no decrease in the prices of public goods and services, which were intended to be ensured according to market principles. Beyond a number of improvements relating in particular to the introduction of the principles and of the performance criteria at the administrative level, a new vision of public administration appeared to be necessary in terms of ensuring a more humane face of public administration and its return to citizens. Such a perspective was aimed at the New Government.

\section{New Government and E-government in Public Administration}

For Finner, the New Government involves the following mechanisms of operation: the minimum state intervention in order to guarantee the public services and goods; a corporate governance - in the sense of identifying from different perspectives the administrative institutions and accepting a collaborative formula for the management of the goods and of the services; the development and the promotion of networks to guarantee the public goods involving actors from different levels (also supranational level) (Finner, 1970: 3-4). Luhmann 
(1982: 6) argues that central government is no longer the determining factor in defining the idea of public administration. We live in "the centreless society"(Luhmann 1982: xv); in the polycentric state characterised by multiple centres. The task of government is to enable sociopolitical interactions; to encourage many and varied arrangements for coping with problems and to distribute services among the several actors. Such new patterns of interaction abound: for example, self-and co-regulation, public-private partnerships, co-operative management, and joint entrepreneurial ventures (Rhodes, 1996: 12).

Stoker defines the following features of the New Government:

1. Governance refers to a set of institutions and actors that are drawn from but also beyond the Government. It challenges the authority of the State or the Government in the traditional sense and maintains that the Government is not the only power center of a state. As long as the power exercised by a public or private institution is recognized by the public, it is possible to become a power center at a specific level.

2. Governance identifies the blurring of boundaries and responsibilities for tackling social and economic issues. It indicates that, in modern society, the State is transferring its once exclusive responsibilities to civil society (i.e., private sector organizations and voluntary groups, which are undertaking more and more responsibilities that were formerly in the hands of the State). As a result, the boundaries between the State and society and between public and private sectors are becoming increasingly blurred, as are definitions of their responsibilities.

3. Governance identifies the power dependence involved in relationships between institutions involved in collective action. To be specific, every organization devoted to collective action has to depend on other organizations; to achieve its purpose, it has to exchange resources and negotiate a common goal with others, and the outcome of the exchange depends not only on the resources of each actor, but also on the rules of the game and the environment in which the exchange takes place.

4. Governance emphasizes the importance of autonomous self-governing networks of actors. A self-governing network as such has the authority to issue orders in a certain sphere and work with the Government in this sphere and share its responsibilities for public administration.

5. Governance recognizes the capacity to get things done without relying on the power of the Government to command or use its authority. In public affairs management, there are other management tools and techniques and the Government has the responsibility to use them to steer and guide public affairs (Stoker, 1999: 21).

For Keping, The New Government refers to:

Legitimacy. It refers to the state or quality that social order and authority are voluntarily recognized and obeyed. It has no direct relevance to laws and regulations, and from the legal angle something legal is not necessarily legitimate. The higher the degree of legitimacy is, the higher the level of good governance will be. The principal approach to achieving and improving legitimacy is to maximize the consensus and political identity shared by citizens. Therefore, good governance requires the relevant administrative bodies and administrators to manage various conflicts of interest among citizens and between them and the State.

Transparency. It refers to the publicity of political information. All citizens are entitled to the information on State policies that are related to their own interests, including legislative activities, policy-making, legal provisions, policy enforcement, administrative budget, public expenditure and other relevant political information. Transparency requires that the aforementioned political information be duly communicated to citizens through various media vehicles so that they can participate in public policy-making and supervise the process of public administration in an effective manner.

Accountability means holding every person accountable for his or her own behaviour. In public administration, it refers in particular to the duties related to a certain position or 
institution and its corresponding obligations. Accountability means that administrators and administrative bodies must fulfil the functions and obligations of the positions they hold. The more accountability the public, especially public officers and administrative bodies have, the higher the level of good governance will be. In this regard, good governance requires the employment of both law and ethics to enhance the accountability of individuals and institutions.

Rule of law. Essentially, rule of law means that law is the supreme principle in public political administration that should be observed by all government officials and citizens, who should be all equal before the law. The immediate goal of rule of law is to regulate citizens' behaviour, manage social affairs and maintain a normal order in social life, while its ultimate goal is to protect citizens' basic political rights, including freedom and equality. In this sense, rule of law is opposite to rule of man as it both regulates citizens' behaviour and restricts the conduct of the State. It is the arch-enemy of political autocracy. Rule of law is a basic requirement of good governance, which would be impossible without a sound legal system, due respect for the law or a social order based on the law.

Responsiveness. Responsiveness is closely associated with the aforementioned concept of accountability. Essentially, it means that public administrators and administrative bodies must respond to the demands of citizens in a timely and responsible manner, and that it is forbidden to make delays without cause or leave any issue unresolved without response. When necessary, they should proactively solicit advice from citizens, explain their policies to them and answer their questions on a regular basis.

Effectiveness. It has two essential meanings: rational administrative structure, scientifically designed administrative procedures and flexible administrative activities; and minimized administrative costs.

Joop and Koliba affirm that "it is widely recognized that public policy making and public service delivery develop increasingly within multilevel, cross-border settings, in which former demarcations of policy fields become blurred, with a high level of individualization, pluriformity of values, information density and dynamics, and mediatisation (Joop and Koliba, 2013: 2). These trends lead to the proliferation of nonlinear dynamics, strategic surprises, and emergent vulnerabilities and risks. As a result, society is increasingly dealing with wicked problems that require the expansion of knowledge and a problem-solving capacity that cannot be provided by any single entity operating alone. During the last decades, classical public administration and new public management have contributed to fragmentation of governance capacity, while greater coordination and collaboration seem to be required (Joop and Koliba, 2013: 3).

Due to the financial crisis, and failures and scandals in public service delivery, the ideology of neoliberalism that fuelled new public management is under closer scrutiny. New public governance (NPG), based on ideas of network governance, is suggested as an alternative paradigm (Osborne, 2010). Critics see transformations in governance that provide different answers to the complexities faced by governments: emerging forms of trust-based, networked structures of collaboration and coordination, and the use of policy tools to shape network structures and functions. Although these practices are not new, they have gained momentum and make up part of the governance landscape alongside classical public bureaucracy and NPM. Public administration and policy science theories and methodologies have been developed that provide the theoretical and normative underpinning of network governance (Joop and Koliba, 2013: 3).

Summarizing we can say that the New Government is a paradigm that comes after the New Public Management and which emerged when the imposition of the simple principles specific to the management practiced on the market by private economic actors has not paid off. Of course, the introduction of the competition principles and criteria brings with it a full amount of dynamism at the administrative level, but the governance of the public goods and 
services cannot lead to excluded beneficiaries at the level of communities. That is why, more often, the New Government occurs when some crises were generated by the prices that are too high on public goods and services, which has led to impossibility of payment among citizens. In other words, the New Government retains the principles of the New Public Management, but turns its face towards the citizens, towards the idea of good and common help.

Moreover, the New Government clearly transposes the idea of networking at the administrative level and the application of the principles of e-government. The Modern administration must necessarily take into account the extremely rapid development of the technologies, of the new technologies, of the digitalisation.

Literature in the field has mentioned different reasons for the adoption of e-government: political, economical, social and managerial reasons. From the political point of view, egovernment is used to provide public information services with the goal to increase citizen participation in political processes. Economical reasons include lower cost channels of communication with citizens, increased resource efficiency, improved service quality, reduced turnaround times, improved access to services and availability of new services. The social benefits of e-government include better delivery of government services. Public services can be more readily brought to all citizens, particularly those with special needs and the elderly by enabling citizens to obtain government information through web portals at any time and from any location equipped with Internet access. The managerial reasons behind the adoption of egovernment include reforming the public sector, leading to more efficient government management with increased accountability and transparency. This can help reduce corruption and prevent many (but not all) of the human errors that manual processing entails. For employees and managers, it can bring convenience and efficiency (Colesca, Dobrică, 2008: 205).

The internet has become the public space of the 21 st century-the world's town square. The rapid pace of technological development inspired the creation of increasingly advanced information and communication technology (ICT) solutions that are capable of radically transforming both public institutions and private organizations. ICT offers tools for innovative interactions between a government and its citizens and smart ways to provide public services (Solomon, 2020: 75).

Moreover, in this world of the new technologies, the elements of e-government seem to be analysed in a broader context of government that must be carried out in the same context of new technologies. "So, if e-government is understood as the use of ICT to promote more efficient and cost effective government, facilitate more convenient government services and allow greater public access to information, and make government more accountable to citizens, then e-governance is a wider term which covers the state's institutional arrangements, decision-making processes, implementation capacity and the relationship between government officials and the public" (Shailendra, 2011).

\section{Conclusions}

The current public administration has naturally undergone a number of changes that have occurred over time from various sources. We can talk about political changes: in the sense that the modification of state structures and supra-state constructions (such as the creation and the consolidation of the EU) that has brought with it the need to rethink the construction of the public administration from the local to the supra-state level; about economic changes - in the sense that the national markets are very often driven by the evolution of the global markets, implicitly by their fluctuations or stock markets, which - in the light of the global crises - means also the need to modify the administrative institutions; about demographic changes and mobility - which implies that the administrative institutions themselves must 
adapt to new problems, such as labour mobility, etc., and rethink their structure and services; about technological changes - which implies the accelerated process of ICT development in relation to which the administration must adapt in the sense of digitising as much as possible the processes, of providing access in this way to as much information or public services and goods as possible.

In conclusion, just as the whole world is constantly changing and re-adjusting, including through the prism of the current pandemic of COVID-19, so the administrative institutions must adapt to the new world in which we live, to the new challenges in order to respond better to the management of the public goods, which means that the paradigms of the explanation and of the analysis themselves are adapted as such.

In other words, any kind of digitization process, including at the administrative level, assumes that the e-government systems to have behind them some people and collaboration formulas. If they will not work very well, then the processes of certain online public services will not be functional either.

The public administration in the current era of the COVID 19 pandemic meant the need to achieve the distance of the citizens, so that several public services were transferred online. E-government becomes a fundamental dimension at the administrative level, in a more general context in which the EU is increasingly talking about the strategy of digitising the public administration, implicitly financing the strategy through certain related funding lines for the Member States.

On the other hand, the current world in pandemic is determined by a fairly high degree of discretionary decisions of the public administration from the central level to the local level, showing in fact that the current public administration is not prepared for the crisis management. „Cooperation is also advocated by recent contributions on COVID-19 and "wicked problems" in general, which are characterized by uncertainty and consequences that cross traditional policy boundaries. Due to these characteristics, wicked problems such as the COVID-19 pandemic can hardly be addressed by single actors, who will therefore have to create networks to organize effective responses" (Malandrino, Demichelis, 2020:9).

In conclusion, the current public administration even in the pandemic period must find the best formulas of collaboration between specialists in order to be able to offer public services through the prism of the most modern technologies, but beyond that, the human side cannot be totally removed, no matter how much others try this.

\section{References}

1. A. Androniceanu, A. Tendințe noi în managementul public internaţional şi oportunitatea adaptării şi implementării lor în instituţiile publice din România, Administraţie şi Management Public, vol, 1, pp. 7-19, (2003)

2. A. Adroniceanu, A. Şandor. Impactul Noului Management Public asupra administraţiei publice din România, Administraţie şi Management, vol. 6, pp. 13-19, (2006).

3. S. E. Colesca, L. Dobrică. Adoptaion and use of e-government services: a case of Romania, Journal of Applied Research and Technology, Vol. 6 No. 3 December, pp. 204-216, (2008).

4. V. Doorgapersad. Paradigm shift from New Public Administration to New Public Management: theory and practice in Africa, Td The Journal for Transdisciplinary Research in Southern Africa, 7(2), pp. 235-250, (2011).

5. S. E. Finer. Comparative Government. London: AllenLane, The Penguin Press, (1970).

6. G. Gruening. Origin and Theoretical Basis of New Public Mananagement, International Public Management Journal, vol. 4, pp. 1-25, (2001).

7. K. Joop, C. Koliba, C. Transformations towards new public governance: Can the New Paradigm Handle Complexity?, International Review of Public Administration, Vol. 18, No. 2, (2013).

8. M. Lee. Conceptualizing the New Governance: A New Institution of Social Coordination, Institutional Analysis and Development Mini-Conference, Workshop in Political Theory and Policy Analysis, Indiana University, Bloomington, Indiana, USA, pp.3-26, (2003). 
9. N. Luhmann. The Differentiation of Society. New York, Columbia University Press, (1982).

10. J. Maesschalck. The Impact of new Public Management Reforms on public sevants ethics: towards a theory, Public Administration, Vol. 82 No. 2, pp. 465-489, (2004).

11. A. Malandrino, E.Demichelis E. Conflict in decision making and variation in public administration outcomes in Italy during the COVID-19 crisis. European Policy Analysis. 2020;10:1-9. 10.1002/epa2.1093 (2020).

12. S. Osborne. The New Public Governanc?, Public Management Review, ISSN 1471-9037 print/ISSN 1471-9045, pp. 377-387, (2006).

13. S. Osborne. The New Public Governance: Emerging Perspectives on the Theory and Practice of Public Governance. London: Routledge, (2010).

14. R.A.W. Rhodes. Governance and Public Administration. University of Newcastle, Newcastleupon-Tyne, (1996).

15. C. Shailendra (coord). E-Government and E-Governance: Definitions/Domain Framework and Status around the World. Online: https://www.academia.edu/6283380/E-Government_and_EGovernance_Definitions_Domain_Framework_and_Status_around_the_World.

16. O. Solomon. E-governance Analitical Reflexions, Administrarea Publică, nr. 3, pp.74-82, (2020).

17. G. Stoker. Governance as theory: Five propositions. International Social Science Journal, No. 50:

17-28. (Chinese edition), (1999). 